\title{
Flowers Characteristics of Selected Species of Lime-Tree (Tilia spp.) in Terms of miRNA-Based Markers Activity, Mannose Expression and Biological Compounds Content
}

\author{
Katarína Ražná ${ }^{1, *(1)}$, Jana Žiarovská ${ }^{1}$, Eva Ivanišová ${ }^{2} \mathbb{D}$, Lucia Urbanová ${ }^{3}$, L'ubomír Harenčár ${ }^{1}$, Adam Kováčik ${ }^{1}$, \\ Matúš Kučka ${ }^{1}$ and Pavel Hrubík ${ }^{4,+}$ \\ 1 Institute of Plant and Environmental Sciences, Faculty of Agrobiology and Food Resources, \\ Slovak University of Agriculture, Tr. A. Hlinku 2, 94976 Nitra, Slovakia; jana.ziarovska@uniag.sk (J.Ž.); \\ xharencar@uniag.sk (L'.H.); xkovacika1@uniag.sk (A.K.); xkucka@uniag.sk (M.K.) \\ 2 Institute of Food Sciences, Faculty of Biotechnology and Food Sciences, Slovak University of Agriculture, \\ Tr. A. Hlinku 2, SK-94976 Nitra, Slovakia; eva.ivanisova@uniag.sk \\ 3 Research Centre AgroBioTech, Slovak University of Agriculture, Tr. A. Hlinku 2, 94976 Nitra, Slovakia; \\ xzamieskova@uniag.sk \\ 4 Faculty of Agrobiology and Food Resources, Slovak University of Agriculture, Dunajská 16, \\ SK-94912 Nitra, Slovakia; ginkgo.ph@gmail.com \\ * Correspondence: katarina.razna@uniag.sk; Tel.: +421-37-6514240 \\ + Retired.
}

Citation: Ražná, K.; Žiarovská, J.; Ivanišová, E.; Urbanová, L.; Harenčár, L'.; Kováčik, A.; Kučka, M.; Hrubík, P. Flowers Characteristics of Selected Species of Lime-Tree (Tilia spp.) in Terms of miRNA-Based Markers Activity, Mannose Expression and Biological Compounds Content. Forests 2021, 12, 1748. https:// doi.org/10.3390/f12121748

Academic Editor: Filippos

A. Aravanopoulos

Received: 5 November 2021

Accepted: 8 December 2021

Published: 11 December 2021

Publisher's Note: MDPI stays neutral with regard to jurisdictional claims in published maps and institutional affiliations.

Copyright: (c) 2021 by the authors. Licensee MDPI, Basel, Switzerland. This article is an open access article distributed under the terms and conditions of the Creative Commons Attribution (CC BY) license (https:// creativecommons.org/licenses/by/ $4.0 /)$.

\begin{abstract}
The significant healing effect of Tilia platyphyllos SCOP. and Tilia cordata MILL. flowers are well known. However, the flowers of Tilia tomentosa Moench. are not suitable for harvest due to their toxic effects. To investigate the diverse background of this effect, we applied a functional miRNAbased marker, mannose expression analysis and determined the content of bioactive compounds. Out of nine tested markers, three (miR160, miR167 and miR408) provided reproducible miRNA-based loci and two of them (miR160 and miR398) enabled the acquisition of fingerprinting specific to flower and leaf samples of T. platyphyllos and T. tomentosa. The most pronounced profiling was specific for miR408 marker, the function of which is connected to plant defense and adaptation mechanisms. We confirmed the suitability of microRNA-based markers for polymorphism determination of flowers of selected species of lime-tree. The highest values of antioxidant activity, flavonoids, total polyphenols and phenolic acids content have been reached in silver linden flowers. When comparing the transcription activity of mannose in flowers, more than 30 times higher levels of mannose transcripts for the silver linden flowers was observed.
\end{abstract}

Keywords: linden; flowers; microRNAs; mannose; antioxidants

\section{Introduction}

The species of lime-tree (Tilia spp.) from the Malvaceae family are beautiful, stout trees with a dense, shady crown. They grow to a height of $30 \mathrm{~m}$ and can live up to 700 years. It is a symbol tree of the Slavs for its longevity, power and beauty. King Matej's lime tree, growing near Bojnice Castle in Slovakia, is one of the oldest trees in Europe [1,2]. In Europe, there are mainly found Tilia platyphyllos Scop. (large-leaved linden), Tilia cordata Mill. (small-leaved linden) and Tilia tomentosa Moench. (silver linden) [3]. The lime-tree is deeply rooted and rejuvenates from stumps. The flowers are yellowish, fragrant and honey-bearing. They are widely used in horticulture [2]. For proven healing effects, mainly flowers of large-leaved linden and small-leaved linden are collected. The pharmaceutical and environmental values make the lime-tree the "tree of the future" [1]. For silver linden (blooms in late June and early July), the collection of flowers for these purposes is not recommended, due to their toxicity. In terms of the presence of different pollinators, individuals of the honeybee dominate the large-leaved linden and the small-leaved linden. 
However, the silver lime is dominated by various species of bumblebees, flies, or other, unspecified species of insects [4]. Tilia cordata Mill. (syn. T. parvifolia Ehrh.), a small-leaved linden, grows from the lowlands to the lower mountain ranges. The leaves are round heart-shaped, gray on the back and rusty hairy at the angles of the veins. Weakly ribbed drupes can be crushed between fingers. Tilia platyphyllos Scop. (syn. T. grandiflora Ehrh.), the large-leaved linden, has an overall appearance of the previous one. The occurrence is similar, but it extends to higher mountain ranges (up to a height of $1200 \mathrm{~m}$ above sea level). However, it buds and blooms more often. The leaves are larger and more asymmetrical, green on both sides, with whitish hairs at the veins of the veins. The drupes cannot be crushed between fingers. Both domestic species interbreed with each other. Tilia tomentosa Moench. (syn. T. argentea Desf.), the silver linden, has a conical crown with wide protruding branches. The shoots are hairy and the leaves on the back are grayish white felted with a shorter stalk. It blooms only in the second half of July and has a pleasant smell. It is very valuable and suitable for urban environments [1-3]. Due to its resistance to polluted air, drought resistance and frost resistance, it is one of today's most important trees in various major cities in Europe [5].

Several studies have been focused on genetic diversity and structure of lime-tree in urban and forest ecosystems assessed by RAPD [6,7], ISSR [8] and SSR markers [9-11], including plastid genome sequencing [12]. However, the miRNA-based markers have not yet been applied to this species. MicroRNAs molecules are an integral part of a gene regulation mechanism. As such, they are a part of comprehensive processes of plant development, plant organ formation, and they significantly participate in plant protection mechanisms against biotic and abiotic stress factors. For this reason, miRNA markers are commonly referred to as stress biomarkers [13-17]. Precursor molecules of miRNA (pre-miRNA) create specific stem-loop structures, which are characterized by genomic conservation of miRNA sequences. This unique feature of the stem-loop region provides an opportunity to develop a novel type of molecular markers [18]. The miRNA-based marker system is relatively polymorphic and reproducible and with putative functionality [19]. The high level of transferability across species demonstrates the usability of miRNA-based markers for genome mapping and phylogenetic studies [20]. Given the origin of markers, of which sequences correspond to the miRNA genomic sequences, they can be considered as functional markers at the DNA levels [19-21]. The microRNA-based genotyping technique has been applied in Brassica species [19], Setaria italica (L.) P. Beauvois and in related grass species [20], Oryza sativa (L.) [22,23], Medicago truncatula Gaertn. and related legume species [24], Linum species [25] and Ginkgo biloba (L.) [26].

A phenomenon linked to mass bee deaths has been reported for Tilia tomentosa due to the toxic components of nectar [27] but not for other linden species [28]. Different lime metabolites were identified as toxic, but mannose was reported to be toxic specifically for honeybees and bumblebees [29] and the toxicity effect has been further discussed in literature in opposite ways as the background molecule causing the bees death $[30,31]$. Mannoses disturb carbohydrate metabolism in bees [32] and beside the linden trees, this molecule was detected in nectar of other plants, such as Tordylium apulum (L.) or Cistus salvifolius (L.) [32].

The purpose of our work was to point out possible differences connected to linden flowers properties using functional microRNAs markers, mannose expression and biological compounds content. We aimed to test the hypothesis that functional miRNA-based markers might be linked to some specific properties of silver linden flowers. To our knowledge, interdisciplinary, molecular-biochemical approaches to the study of linden flowers' properties, has not yet been applied.

\section{Materials and Methods}

\subsection{Plant Materials and Sample Preparation}

Plant material (whole inflorescences including bracts and leaves) for analysis was obtained from three species of lime tree: Tilia platyphyllos Scop. (large-leaved linden), Tilia 
cordata Mill. (small-leaved linden) and Tilia tomentosa Moench. (silver linden) growing in an urban area at the time of intensive flowering (late May, June and early July 2019). Samples of flowers, bracts and leaves (Figure 1) were collected randomly from the tree and were obtained from two trees of each species. Separated parts (flowers, bracts and leaves) were stored at $-20^{\circ} \mathrm{C}$ till further analyses.

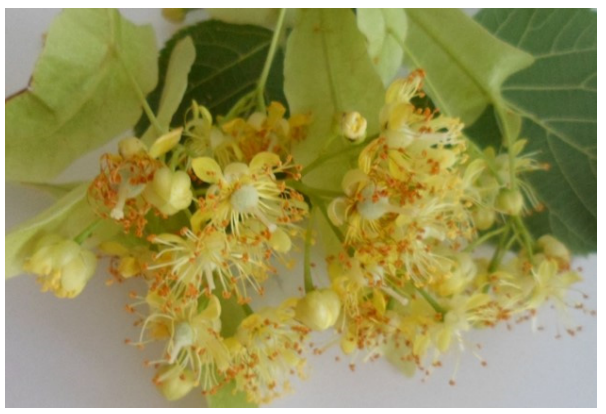

(a)

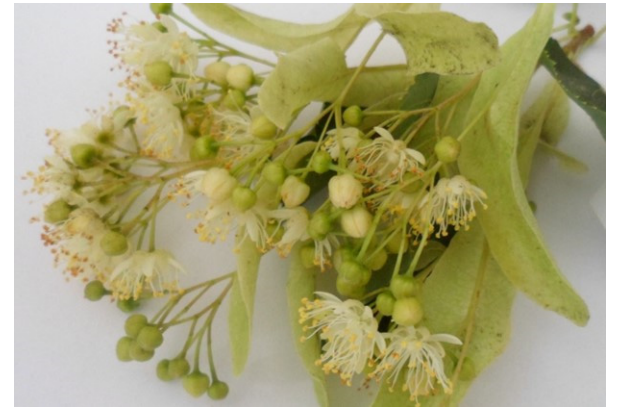

(b)

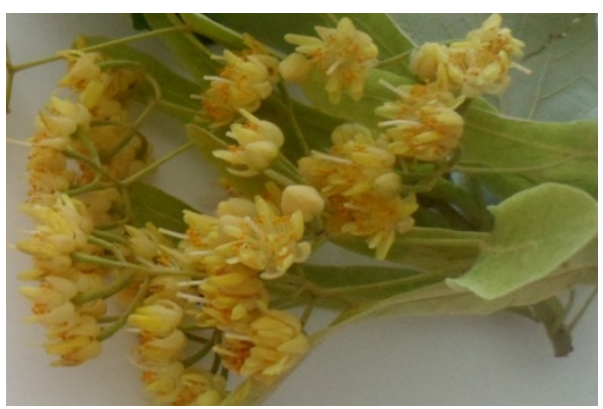

(c)

Figure 1. Flowers of (a) Tilia platyphyllos Scop. (large-leaved linden); (b) Tilia cordata Mill. (smallleaved linden); (c) Tilia tomentosa Moench. (silver linden).

\subsection{Nucleic Acids Extraction}

Subsequently, the pooled samples of flowers, bracts and leaves were prepared in liquid nitrogen and genomic DNA was isolated by NucleoSpin Plant II extraction kit (Macherey Nagel, GmbH \& Co. KG, Düren, Germany). Isolated DNA was quantified by nanophotometer Implen P360 (Implen $\mathrm{GmbH}$, Muenchen, Germany) and diluted to a concentration of $70 \mathrm{ng} \times \mu \mathrm{L}^{-1}$. Total RNA was extracted by Ribospin Seed/Fruit (GeneAll Biotechnology Co., Ltd., Seoul, Korea) from flowers and leaves and checked for its quantity and quality using the nanophotometer. Extracted RNAs were normalized to $30 \mathrm{ng} \times \mu \mathrm{L}^{-1}$ and the transcription was performed by Tetro cDNA Kit (Bioline, Meridian Bioscience, TN, USA) following the instructions of the manufacturer and using oligo (dT)18 primers.

\subsection{MiRNA-Marker Assay}

The original protocol [19,20] was modified [33] and applied as follows: PCR was amplified in a PCR mix $20 \mu \mathrm{L}$ containing $70 \mathrm{ng}$ of genomic DNA, $10 \mathrm{pmol} \times \mathrm{dm}^{-3}$ of each primer, 2 U of DreamTaq DNA polymerase (ThermoFisher Scientific Inc., Naarden, The Netherlands), $0.8 \mathrm{mmol} \times \mathrm{dm}^{-3} \mathrm{dNTPs}$ (Invitrogen, ThermoFisher Scientific Inc., Naarden, The Netherlands) and $1 \times$ DreamTaq Buffer $\left(\mathrm{KCl},\left(\mathrm{NH}_{4}\right)_{2} \mathrm{SO}_{4}, 20 \mathrm{mmol} \times \mathrm{dm}^{-3}\right.$ $\mathrm{MgCl}_{2}$ ). The PCR amplification program used the 'touchdown' method as follows: initial denaturation at $94{ }^{\circ} \mathrm{C}$ for $5 \mathrm{~min} ; 5$ cycles of $30 \mathrm{~s}$ at $94{ }^{\circ} \mathrm{C}, 45 \mathrm{~s}$ at $64{ }^{\circ} \mathrm{C}$ (with a $1{ }^{\circ} \mathrm{C}$ decrease in annealing temperature per cycle), and $60 \mathrm{~s}$ at $72{ }^{\circ} \mathrm{C} ; 30$ cycles of $30 \mathrm{~s}$ at $94{ }^{\circ} \mathrm{C}, 45 \mathrm{~s}$ at $60{ }^{\circ} \mathrm{C}$, and $60 \mathrm{~s}$ at $72{ }^{\circ} \mathrm{C}$; and the final extension at $72{ }^{\circ} \mathrm{C}$ for $10 \mathrm{~min}$. The samples were subsequently stored at $8{ }^{\circ} \mathrm{C}$. PCR assays were carried out in duplicates. Amplificated products were separated on 3\% agarose and Novex ${ }^{\mathrm{TM}}$ TBE-Urea gels, $15 \%$ (Invitrogen, ThermoFisher Scientific Inc., Naarden, The Netherlands), running in $1 \times$ TBE Running 
Buffer at constant power $180 \mathrm{~V}, 30 \mathrm{~mA}$ for $90 \mathrm{~min}$. The gels were stained with PAGE GelRed $^{\mathrm{TM}}$ Nucleic Acid Gel stain (Biotium, Inc., Fremont, QC, Canada) and visualized on G-Box (Syngene, Synoptics Ltd., Cambridge, UK) electrophoresis documentation system. For the recording of loci number and their position, as well as the identification of unique fragments, the gels were analyzed by GeneTools software (version4.3.10.0, Syngene, Synoptics Ltd., Cambridge, UK).

\subsection{Design of miRNA Primers}

The primers for miRNA-based markers were designed according to the mature or precursor sequences (pre-miRNA) (available in the miRBase database (http:/ / www.mirbase. org release 22.1), accessed on 18 May 2020) [34] based on the methodology [19,20]. The database does not contain sequences of lime-tree species; within the family Malvaceae, it includes sequences of Gossypium species and Theobroma cacao L. We applied markers based on miRNAs sequences of the following species: Gossypium, Malus, Linum, Hypericum and Glycine. Our previous studies have confirmed species transferability of miRNA-based markers; therefore, we selected the following types of markers of above-mentioned species: miR156, miR160, miR167, miR171, miR396, miR398, miR408 and miR414. All of them represent conserved miRNA families.

\subsection{Primer Design for Mannose Expression Analysis and Real-Time PCR Analysis}

Bioinformatic screening and BLAST based design was used for primers of mannose expression analysis, because the nucleic acid data specific for linden mannose gene does not exist. A total of five sequences for mannose pathway regulator are available in the NCBI database and these were BLASTed for finding a conserved part of them. The following nucleotides of the accession NM_105129.1 were found to be conserved and these were used for primer designation: nucleotides 909-941 and nucleotides 1001-1021. Actin was used in the analysis as a housekeeping gene. The reactions were performed in ElizymeMix with ROX 2X (Elizabeth Pharmacon, Ltd., Croydon, UK) and the following profile of real-time PCR was used: $95^{\circ} \mathrm{C} 2 \mathrm{~min}\left(95^{\circ} \mathrm{C} 5 \mathrm{~s} ; 60^{\circ} \mathrm{C} 25 \mathrm{~s}\right) 40 \times$ plus melt analysis. A delta delta $\mathrm{Ct}$ approach was used to compare the expression levels of mannose transcription activity among the individual combinations of linden species or tissues.

\subsection{Analyses of Antioxidant Activity}

\subsubsection{Free Radical Scavenging Activity}

2,2-diphenyl-1-picrylhydrazyl (DPPH) was used to determine free radical scavenging activity in accordance with the method described by [35]. Briefly, the absorbance of samples $(0.4 \mathrm{~mL})$ and alcohol solution DPPH $(3.4 \mathrm{~mL})$ were measured at a wavelength of $515 \mathrm{~nm}$ using a spectrophotometer (6405 UV/Vis, Jenway, Stone, UK). The results of antioxidant activity were expressed as Trolox (6-hydroxy-2,5,7,8-tetramethylchroman-2-carboxylic acid) equivalent in $\mathrm{mg} / \mathrm{g}$.

\subsubsection{ABTS Radical Cation Decolorization Assay}

ABTS radical cation decolorization assay was determined by the method [36] with slight modifications. Trolox $\left(100-100 \mathrm{mg} / \mathrm{L} ; R^{2}=0.9991\right)$ was used as a standard, and the results were expressed in $\mathrm{mg} / \mathrm{g}$ FM of Trolox equivalents.

\subsubsection{Total Polyphenol Content}

A standard method [37] was used to measure the total polyphenol content in analyzed samples. The results of absorbance at $700 \mathrm{~nm}$ measured spectrophotometrically (6405 UV/Vis, Jenway, Stone, UK) were then calculated and expressed as gallic acid equivalents expressed in $\mathrm{mg} / \mathrm{g}$. 


\subsubsection{Total Flavonoid Content}

Total flavonoid content was measured spectrophotometrically (6405 UV/Vis, Jenway, Stone, UK) at $415 \mathrm{~nm}$ according to the method [38]. Briefly, to a $0.5 \mathrm{~mL}$ sample, ethanolic solution of aluminum chloride $(10 \% w / v)$, potassium acetate $(0.1 \mathrm{~mL}$ of $1 \mathrm{M})$ and distilled water $(4.3 \mathrm{~mL})$ were added. Then, the mixture was incubated in the dark for $30 \mathrm{~min}$. Obtained results were expressed in $\mathrm{mg} / \mathrm{g}$ quercetin equivalents.

\section{Results}

\subsection{MicroRNA Analyses}

In total, nine different types of microRNA-based markers belonging to eight different families of miRNAs were used in the diversity study- miR156, miR160, miR167, miR171, miR396, miR398, miR408 and miR414. Positive amplification has been recorded only in three types of miRNA markers-miR160, miR167 and miR408. In total 27 miRNA loci were amplified by markers based on miR408, where the most (48\%) miRNA loci were detected in flower samples, $30 \%$ in leaf samples and $22 \%$ in bracts samples. The most significant amplification of this marker was observed in small-leaved linden flower sample (Figure 2). In the leaf samples, the amplification profile was similar in all three genotypes with the highest amplification effectivness in leaves of large-leaved linden. The most significant amplification by the marker miR 408 was recorded in bracts samples of silver linden (Figure 3).
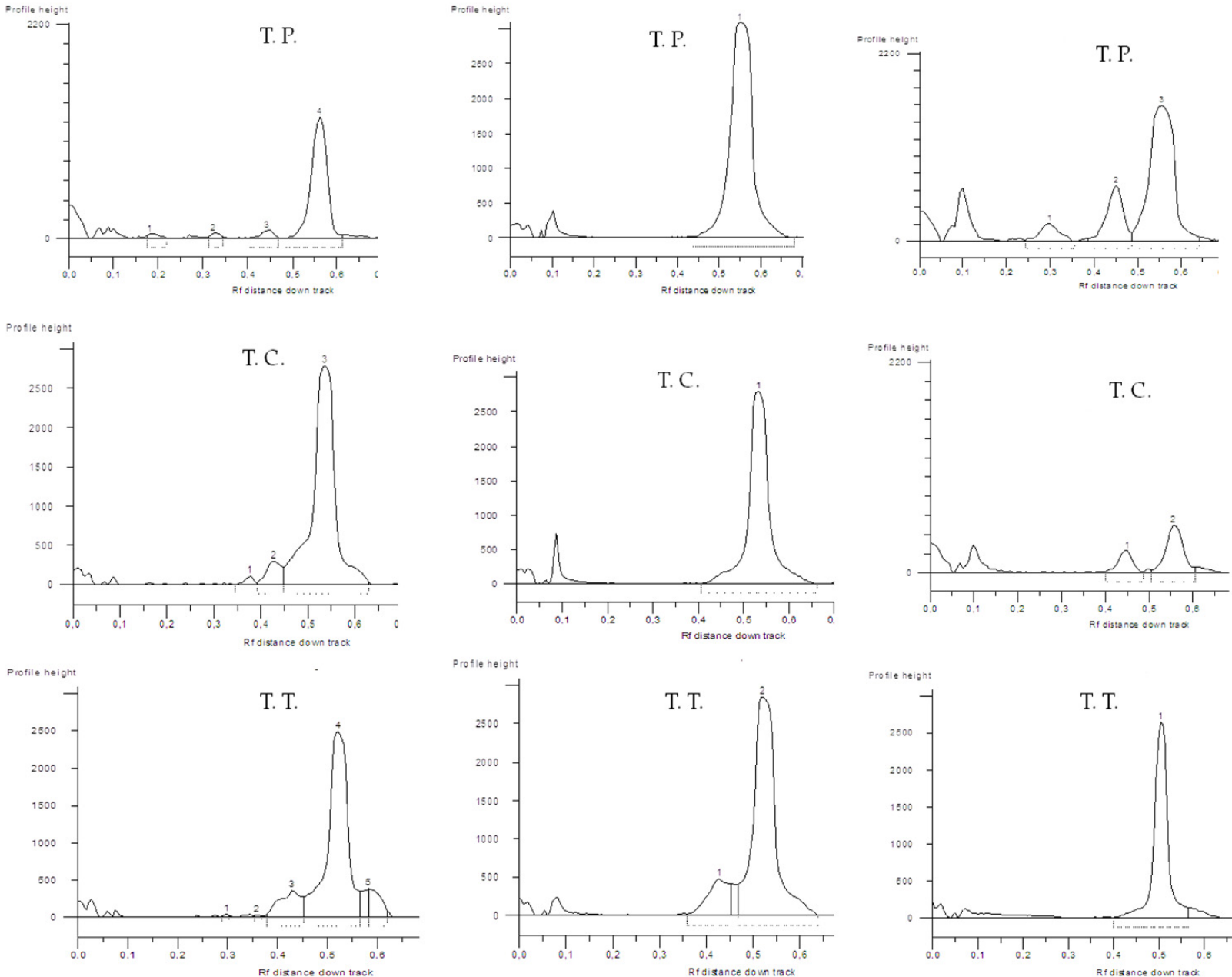

(a)

(b)

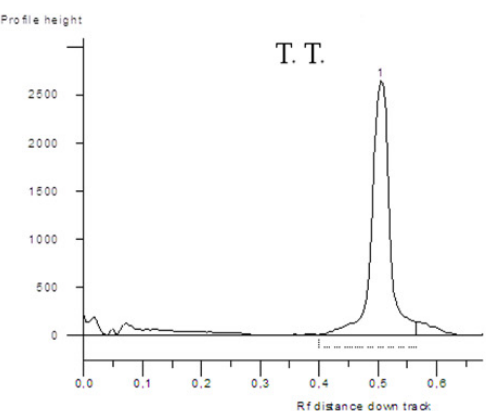

(c)

Figure 2. Amplified profiles of miRNA-based pattern of Tilia platyphyllos (T. P.), Tilia cordata (T. C.) and Tilia tomentosa (T. T.) in samples of flowers (a), leaves (b) and bracts (c) by miR408 marker. 


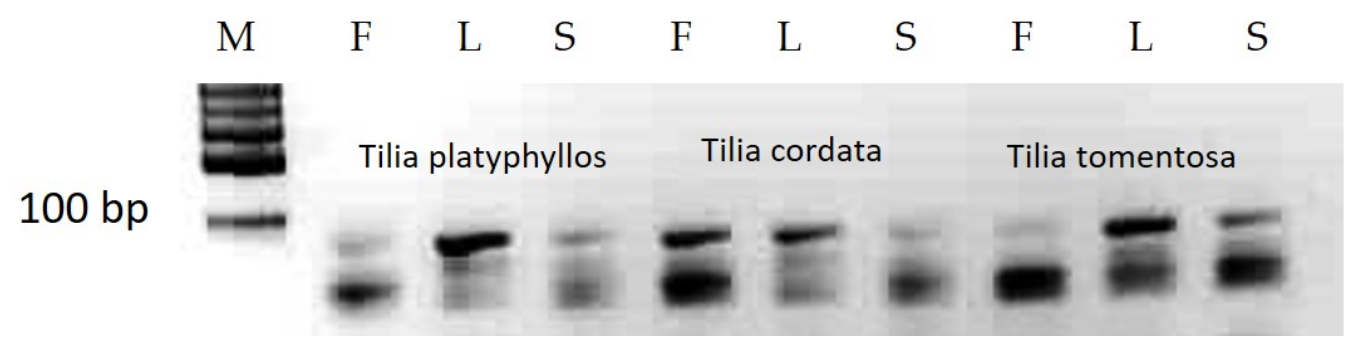

Figure 3. Mir408-based amplification in flowers (F), leaves (L) and bracts (S) of three linden genotypes. M-DNA Ladder.

In total, 26 miRNA loci were amplified by miR160 marker, where leaf and bracts samples were amplified almost $39 \%$ and the flower sample was $23 \%$ of all amplified miRNA loci. The most significant amplification by the marker miR160 was recorded in the flower sample of the small-leaved linden (T. cordata), leaf sample of large-leaved linden (T. platyphyllos) and bracts sample of silver linden (T. tomentosa) (Figure not shown).

The amplification product of miR167-based marker was observed mostly in flower samples of all three linden genotypes (T. platyphyllos, T. cordata and T. tomentosa). In the case of silver linden, fragments were also present in the leaf sample (Figure 4).

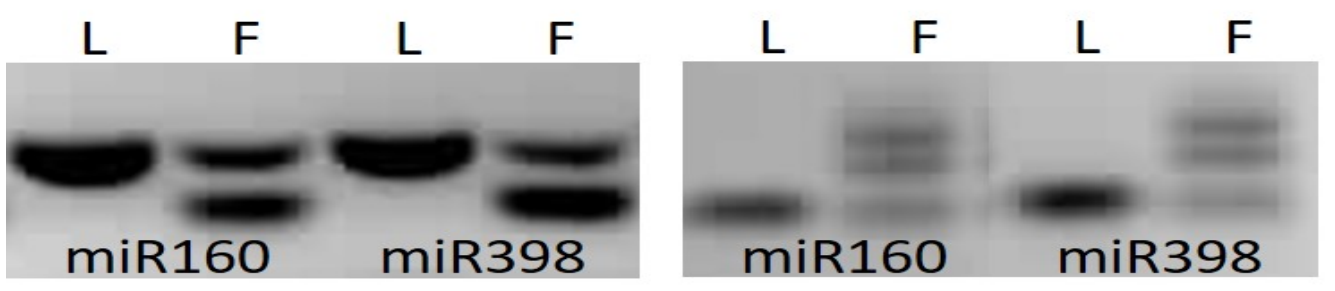

Figure 4. Mir167-based amplification in flowers (F), leaves (L) and bracts (S) of three linden genotypes. M-DNA Ladder.

The amplification product of miR167-based marker was observed mostly in flower samples of all three lime genotypes (T. platyphyllos, T. cordata and T. tomentosa). In the case of silver lime, fragments were present also in leaf sample (Figure 4).

One of the key features of microRNA-based markers is their species transferability, making it possible to derive them from various species and apply within the test species. This feature is dues to conserved nature of miRNAs sequences $[19,20]$. We decided to test the amplification affinity of markers miR160 and miR398 derived from apple (M. domestica) microRNA sequences. Interestingly, both markers have provided specific fingerprinting pattern distinguishing flowers' samples from the leaves in large-leaved linden and silver linden (Figure 5).

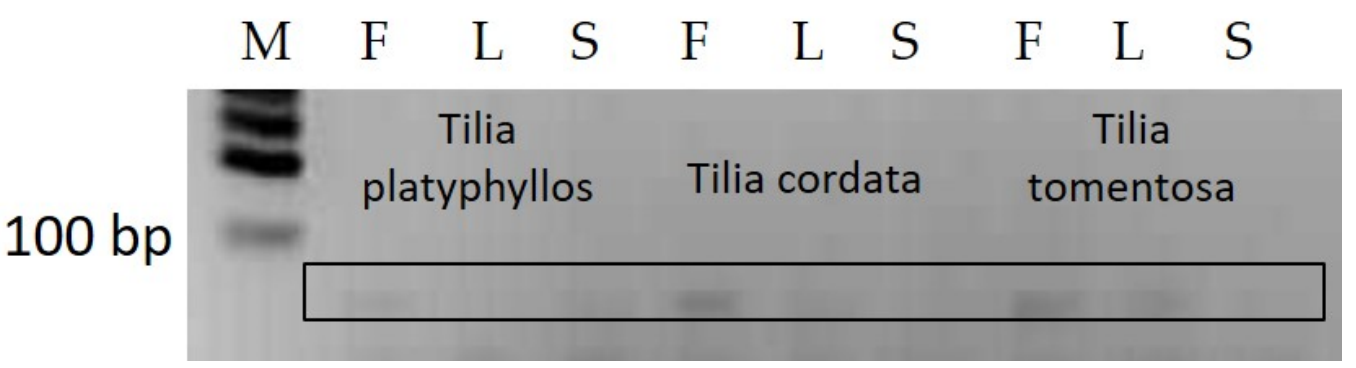

(a)

(b)

Figure 5. Fingerprinting of $m i R 160$ and miR398-based pattern of flower and leaf samples of T. platyphyllos (a) and T. tomentosa $(\mathbf{b})$. 


\subsection{Mannose Pathway Regulator Expression Analysis}

Comparison of mannose transcription activity was analyzed for the following combinations: different linden species for flowers, different linden species for leaves and the comparison of expression change for flowers and leaves of the same linden species. After the optimization of the real-time PCR assay, the Tm of the mannose product was set to $72.2^{\circ} \mathrm{C}$.

When comparing the transcription activity of mannose in flowers of different linden species, the highest fold change was obtained for Tilia tomentosa and Tilia cordata (Figure 6) at the level of more than 30 times higher than the level of mannose transcripts for the flowers of silver linden. The expression of the mannose is nearly the same in the flowers of Tilia platyphylos and Tilia cordata.

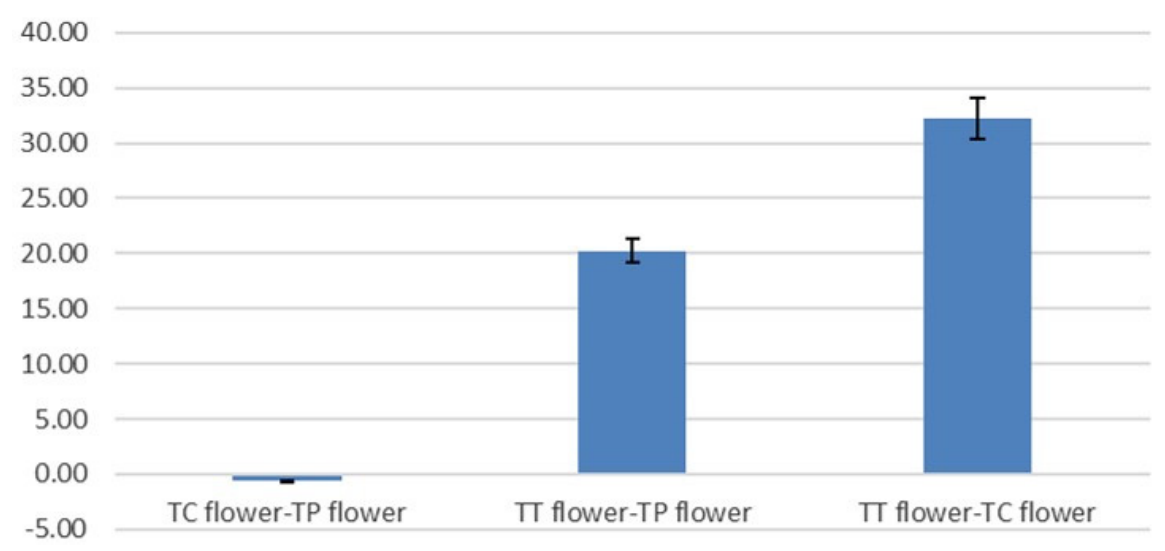

Figure 6. The expression change of mannose in the flowers of different Tilia species.

Similar results were obtained in the case of mannose expression comparisons in leaves of the analyzed linden species but the fold changes were much lower here as in the previous case with the highest change at the level of 2 (Figure 7).

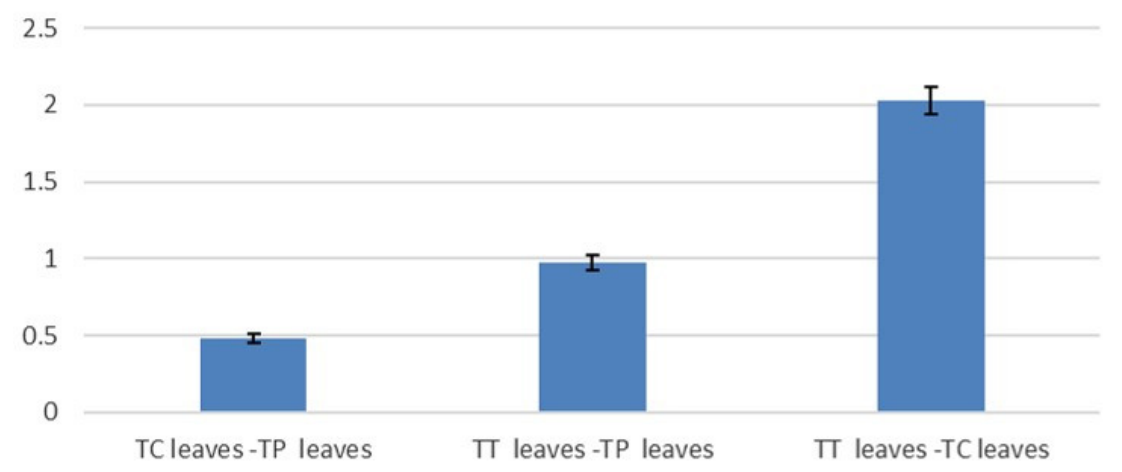

Figure 7. The expression change of mannose in the leaves of different Tilia species.

The lowest fold changes were found when the expression of mannose was compared between the flowers and leaves of the same species. Here, the changes were not higher than physiological differencies (Figure 8). 


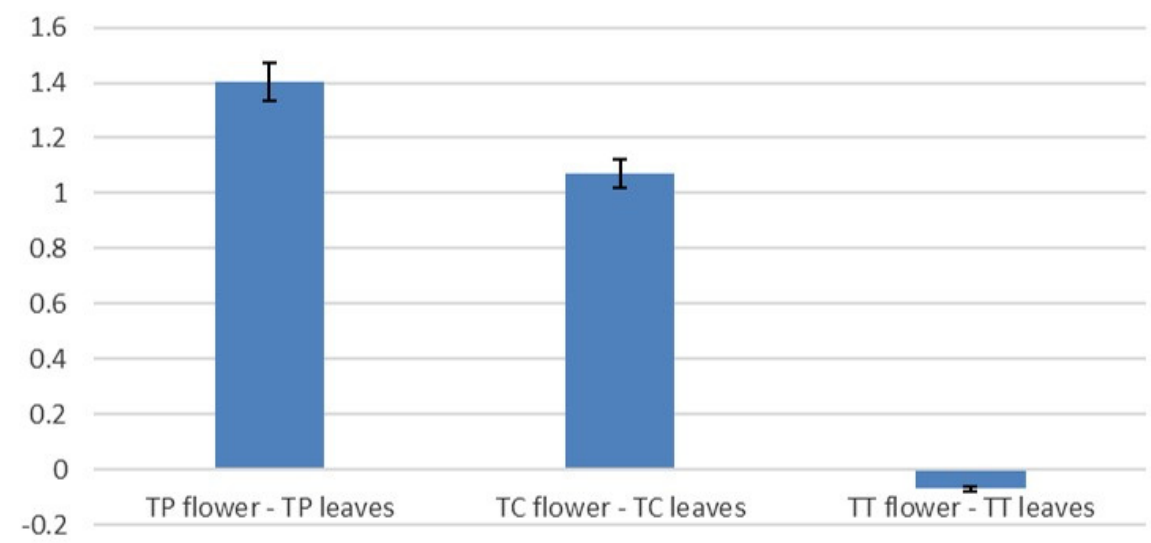

Figure 8. The expression change of mannose in leaves compared to the flowers of analyzed Tilia species.

\subsection{Antioxidant Activity, Total Polyphenol and Total Flavonoid Content}

Antioxidant activity, total polyphenol and total flavonoid content parameters were analyzed in flower samples of three lime genotypes because flowers are the main source of important medicinal properties. Flowers of silver lime showed the best antioxidant activity (Table 1). Almost similar values of antioxidant activity were detected in the flowers of largeleaved lime and small-leaved lime. The other analyzed parameters had a similar outcome. The results indicate that the highest content of total flavonoids, total polyphenols and phenolic acids is presented in flowers of silver lime ( $T$. tomentosa). During the preparation of the extracts, the flowers of the silver lime had the most pronounced scent, and this scent penetrated the extract.

Table 1. Antioxidant activity, total polyphenol, total flavonoid content and total content of phenolic acids of flowers samples of T. platyphyllos, T. cordata and T. tomentosa.

\begin{tabular}{cccccc}
\hline Sample & $\begin{array}{c}\text { DPPH } \\
\text { (mg TEAC/g FM) }\end{array}$ & $\begin{array}{c}\text { ABTS } \\
\text { (mg TEAC/g FM) }\end{array}$ & $\begin{array}{c}\text { TPC } \\
\text { (mg GAE/g FM) }\end{array}$ & $\begin{array}{c}\text { TFC } \\
\text { (mg QE/g FM) }\end{array}$ & $\begin{array}{c}\text { TPAC } \\
\text { (mg CAE/g FM) }\end{array}$ \\
\hline Tilia platyphyllos & 0.593 & 6.952 & 4.274 & 1.904 & 1.538 \\
Tilia cordata & 0.561 & 6.716 & 3.968 & 2.296 & 1.576 \\
Tilia tomentosa & 0.657 & 9.620 & 5.759 & 3.419 & 1.909 \\
\hline
\end{tabular}

TEAC—Trolox equivalent antioxidant capacity; ABTS—radical cation decolorization assay; FM—fresh matter; TPC—total polyphenol content; TFC—-total flavonoid content; TPAC—-total phenolic acids content; GAE—gallic acid equivalent; QE-quercetin equivalent; CAE—caffeic acid equivalent.

\section{Discussion}

Tilia is an ecologically important genus in the Malvaceae family. Lime flowers are an important source of nectar for pollinators, especially in urban areas. Their period of flowering from June to July provides sufficient time for food security of insects [1,2]. There is evidence that flowers of silver linden (Tilia tomentosa Moench) are toxic for insect' visitors [4] nor are they recommended to be collected for human consumption [39]. There is a lack of clinical research assessing the effects of silver linden flowers as well as safety and toxicity data. At the same time, no products containing silver linden flowers are available in the EU [39].

There are various hypotheses justifying the toxicity of silver linden flowers for bees either due to the presence of mannose or nicotine in the nectar or starvation due to insufficiency of the nectar to feed insect visitors [4,40]. Moreover, according to our observations, it is clear that the linden trees are rarely visited by bees, but mainly by other species of insects, such as bumble-bees. However, no trace of mannose or nicotine has been detected in nectar samples in any of the European lime species (T. cordata, T. platyphyllos. T. tomentosa and T. $\times$ europaea) [40]. Metabolic analyses of silver lime nectar have revealed that it does not contain mannose but does contain the pyridine alkaloid trigonelline [41]. The 
authors suggest that behind the bee's mortality is a combination of environmental (low temperature), physiological/sociological (energy deficit of bees that collect nectar despite its shortage and are consequently unable to fly) and biochemical (alkaloids content) factors. A study of sedative and anxiolytic effects of silver lime nectar [42] identified constituents of a flavonoid nature with clear anxiolytic effect. Another study on the side effects of anxiolytic drugs has reported digestive problems [https:/ / www.medicinenet.com/, accessed on 18 May 2020]; flavonoid concentration was one of the factors influencing anticonvulsant and antioxidant properties of Tilia americana var. mexicana flowers and leaves [43].

In all tested attributes (antioxidant activity, total flavonoids content, total polyphenols and phenolic acids content), our results indicate that the highest values were presented in the flowers of the silver linden (T. tomentosa). A number of bioactive compounds can be influenced by several parameters such as climatic conditions, soil, stage of maturity and genotype [44,45]. In our case, the trees from which the samples were obtained grow between residential blocks of an urban settlement (approximately 2 hectares), are the same maturity stage (40-year-old trees) and the soil and climatic conditions are similar. Therefore, from this point of view we can attribute the observed differences to different lime-tree genotypes. Flavonoid fraction is probably responsible for the antiradical properties of lime extracts. The content of biologically active compounds depends on their accumulation during the growing season $[44,45]$. Polyphenols are the main plant bioactive compounds, which act as natural antioxidants [46]. The medicinal potential of the small-leaved lime was tested based on the content of polyphenols in the dry matter of leaves [47]. The ethanolic extracts of Tilia cordata contained polyphenols $(1.37 \pm 0.0021 \mathrm{~g} / 100 \mathrm{~g}$ DW) and indicate high antioxidant activity $\left(\mathrm{IC}_{50}=0.3303 \pm 0.0896 \mathrm{mg} / \mathrm{mL}\right.$ calculated as DPPH scavenging activity). In comparison to our results, the levels of polyphenols and antioxidants were much higher but only in the fresh matter of flowers. A significant antioxidant activity of lime flowers (T. platyphylos, T. cordata and T. $\times$ europaea) was established in water $(63.0 \pm 3.8 \mathrm{mg} / \mathrm{g})$ and ethanol $(36.7 \pm 1.8 \mathrm{mg} / \mathrm{g})$ extracts [47]. In this study, the antioxidant activity was determined using DPPH radical and no statistically significant differences were observed in individual lime genotypes. The antioxidant activity of the water extract of Tilia Argentea Desf ex DC was concentration dependent, but the extract showed no antibacterial activity on the studied microorganisms [48]. Although, most of the studies are focused on antioxidant analyses of linden blossoms and flowers, Tilia cordata fruit extracts also contained 31 phenolic compounds [49].

The silver linden best tolerates polluted air and is characterized by drought and frost resistance, which makes it an integral part of cities [3,5]. Answers to the consequences of the death of pollinators may be found behind these properties. This observation might be supported by the study of local adaptation of 12 isolated populations of silver lime assessed by SSR markers [10]. Significant differences among the populations indicate ongoing adaptation process to local environmental conditions. The involvement of epigenetic mechanisms of regulation of the adaptation process to local environments with just the miRNA molecules representing one of the epigenetic mechanisms of gene expression regulation has been suggested [50,51].

One of the applied markers in our study, miR408, plays an important role in plant genome adaptation against abiotic stress [52]. This marker provided the most effective amplification in flower, leaf and bracts samples of T. platyphyllos, T. cordada and T. tomentosa. Activity of miR408 is significantly affected by a variety of developmental and environmental conditions. Samples were collected from approximately 40 -years-old trees, but from an urban area, which might participate in an abiotic stress response of tested lime trees. The miR408 loci profile has reached the highest levels, mainly in leaf samples of large-leaved lime. One of the target sequences of miR408 in the Malvaceae family are laccases, which are copper containing oxidases [53]. Laccases can oxidize a wide range of substrates, including environment pollutants [54], which could be one of the explanatory factors for environmental adaptability of lime trees. 
Based on our results, the most significant amplification by the marker miR160 was recorded in the flower sample of small-leaved linden (T. cordata), leaf sample of large-leaved lime (T. platyphyllos) and bracts sample of silver lime (T. tomentosa). This is in line with the function of miR160 in development of flowers and floral buds [55]. Target sequences of miR160 are an auxin response factor family of proteins (ARF), especificaly ARF 10, 16 and 17 , which are included in flower organ development [56].

The presence of the miR167 locus, especially in the flower samples of all tested lime genotypes, may be because $m i R 167$ is a part of the regenerative organ development, embryogenesis and seed development mainly through controlling the auxin response factor transcriptional activities [57]. Lower intensity of miR167 activity compared to other markers can be explained by tissue and spatial-specific miRNA activity in the given tissues [58,59].

In our previous experimental studies where miRNA-based markers were applied accross different species (ginkgo, milk thistle, lavender, flax, wheat and barley), the polymorphism level was much higher than in our current study. However, it should be noted that the level of polymorphism depends on the effectiveness of primers' effectiveness as well as on the level of markers' transferability. Some of the primers (miR160, miR 396 and miR398) were designed based on Gossypium species or Malus domestica (BORKH) due to the lack of availability of the microRNAs sequences of Tilia spp. in the miRBase database. The markers miR156, miR167, miR171, miR408 and miR414 originated from miRNA sequences of other species (Linum, Glycine and Hypericum). A possitive reproducible amplification has been recorded in only three types of miRNA markers: miR160 (originated from cotton and apple miRNA sequences), miR167 and miR408 (originated from flax miRNA sequences).

MiRNA-based markers usually demonstrate high polymorphism [19,20]. One of the reasons for the low polymorphism of some of the applied miRNA markers may be the difference in the length of noncoding region caused by insertions in the linden plastid genome compared to the cotton genome [12] based on which the primers were designed. Plastid genome of Tilia spp. is very similar to other sequenced plastid genomes of Malvaceae (Gossypium and Theobroma genera) and consists of 130 genes, of which 113 are unique [12]. Single nucleotide polymorphism in plastid genome of Tilia is defined by $41 \%$ of insertions and $59 \%$ of deletions. Most of these indels are associated with tandem repeats. Further research will be necessary to design and test a wider spectrum of miRNA-based markers.

Genomic analyses of Tilia spp. were so far related to population genetic structure. Microsatellite (SSR, simple sequence repeats) markers were able to discriminate the species T. cordata and T. platyphyllos and their hybrid (Tilia $\times$ europaea) as well as to evaluate the population genetic diversity [11]. The same type of markers reliably recorded a high level of genetic diversity of wild living populations of T. cordata; however, there was low differentiation among tested populations [9] with no evidence of geographic-related adaptation. The number of amplified alleles per locus varied from 5 to 32 by nine SSRs primers. A molecular phylogenetic study employing ISSR markers (inter simple sequence repeats) revealed that the groups of 20 populations of native silver lime have high genetic similarity despite different provenances. These populations were characterized by strong vitality and a large morphologic variability [8]. RAPD markers were used to determine genetic diversity of three Tilia species, including clones (T. tomentosa, T. cordata and T. euchlora). Nine of 12 RAPD primers produced suitable DNA fragments [7]. The authors suggest that the eco-geographic background is an important factor affecting the woody plant genome structure.

We applied miRNA-based markers as functional types of markers whose activity indicates a certain phenotype. Activity of miRNA-based markers miR160, miR167 and miR408 was in line with the role of these molecules in plant tissues. In addition, the miR408, whose proliferation was the most significant, plays an important role in the plant genome adaptation. We can state that our hypothesis to declare suitability of microRNA-based markers for determination of genetic polymorphism of selected species of lime-tree, has been confirmed. The mannose activity and level of bioactive compounds (antioxidant activity, total flavonoids content, total polyphenols and phenolic acids content) has reached 
the highest levels in the flowers of silver linden (T. tomentosa). We can assume that these properties also contribute to the high adaptability of this genotype to urbanized environmental conditions and could have some connection with the properties of nectar of silver lime-tree. Continuing this research by applying more specific miRNA-based markers will broaden our understanding in this area and aid in any future applications of silver linden for urban areas or in the pharmaceutical industry.

Author Contributions: Conceptualization, P.H. and K.R.; methodology, K.R., E.I. and J.Ž.; validation, K.R., E.I., J.Ž. and P.H.; investigation, K.R., J.Ž., L.U., L'H., A.K. and M.K.; resources, P.H.; writingoriginal draft preparation, K.R.; E.I., J.Ž., L.U. and P.H. All authors have read and agreed to the published version of the manuscript.

Funding: This research received no external funding.

Acknowledgments: This publication was supported by the Operational program Integrated Infrastructure within the project: Demand-driven research for the sustainable and innovative food, Drive4SIFood 313011V336, co-financed by the European Regional Development Fund.

Conflicts of Interest: The authors declare no conflict of interest.

\section{References}

1. Machovec, J.; Hrubík, P.; Vreštiak, P. Sadovnícka Dendrológia. (Hodnotenie Biologických Prvkov); Slovenská Pol'nohospodárska Univerzita: Nitra, Slovakia, 2000; p. 228, ISBN 80-7137-702-3.

2. Hrubík, P. Listnaté Dreviny v Sadovníckej Tvorbe; Slovenská Pol'nohospodárska Univerzita: Nitra, Slovakia, 2002; p. 139, ISBN 808069-125-8.

3. Hurych, V. Sadovníctvo, Sadovnícka Dendrológia 2, 1st ed.; PRÍRODA: Bratislava, Slovakia, 2000; p. 204, ISBN 80-07-01148-X.

4. Jacquemart, A.L.; Moquet, L.; Ouvrard, P.; Quentin-Leclerco, J.; Hérent, M.F.; Quinet, M. Tila trees: Toxic or valuable resources for pollinators? Apidologie 2018, 49, 538-550. [CrossRef]

5. Manea, M.I.; Borlea, G.F.; Tenche-Constantinescu, A. Aspects of genetic diversity of silver lime (Tilia tomentosa Moench) populations in natural forests of western Romania. In Proceedings of the SGEM2017 GREEN Conference, 17th International Mul-Tidisciplinary Scientific GeoConference, Vienna, Austria, 27-29 November 2017; 51 Alexander Malinov blvd: Sofia, Bulgaria; Volume 17, pp. 473-480. [CrossRef]

6. Banfi, E.; Consolinová, F. STROMY v Záhradách, v Parkoch a vo Vol’nej Prírode; IKAR a.s.: Bratislava, Slovakia, 2001; ISBN 80-7118995-2.

7. Filiz, E.; Birbilener, S.; Ozyigit, I.I.; Kulac, S.; Orus, F.C.S. Assessment of genetic variations of silver lime (Tilia tomentosa Moench.) by RAPD markers in urban and forest ecosystems. Biotechnol. Biotechnol. Equip. 2015, 29, 631-636. [CrossRef]

8. Gabur, I.; Lipşa, F.D.; Adumitresi, L.; Tanase, C.; Simioniuc, D.P. Assessment of genetic variation of Tilia tomentosa by RAPD markers. J. Plant Dev. 2019, 26, 85-91. [CrossRef]

9. Erichsen, E.O.; Wolff, K.; Hansen, O.K. Genetic and clonal structures of the tree species Tilia cordata Mill. in remnants of ancient forests in Denmark. Popul. Ecol. 2019, 61, 243-255. [CrossRef]

10. Lobo, A.; Hansen, O.K.; Hansen, J.K.; Erichsen, E.O.; Jacobsen, B.; Kjaer, E.D. Local adaptation through genetic differentiation in highly fragmented Tilia cordata populations. Ecol. Evol. 2018, 8, 5968-5976. [CrossRef] [PubMed]

11. Logan, S.A.; Phuekvilai, P.; Wolff, K. Ancient woodlands in the limelight: Delineation and genetic structure of ancient woodland species Tilia cordata and Tilia platyphyllos (Tiliaceae) in the UK. Tree Genet. Genomes 2015, 11, 52. [CrossRef]

12. Cai, J.; Ma, P.F.; Li, H.T.; Li, D.Z. Complete plastid genome sequencing of four Tilia species (Malvaceae): A comparative analysis and phylogenetic implications. PLoS ONE 2015, 10, 0142705. [CrossRef]

13. Bej, S.; Basak, J. MicroRNAs: The Potential Biomarkers in Plant Stress Response. Am. J. Plant Sci. 2014, 5, 748-759. [CrossRef]

14. Chiou, T.J. The role of microRNAs in sensing nutient stress. Plant Cell Environ. 2007, 30, 323-332. [CrossRef]

15. Kruszka, K.; Pieczynski, M.; Windels, D.; Bielewicz, D.; Jarmolowski, A.; Szweykowska-Kulinska, Z.; Vazquez, F. Role of microRNAs and other sRNAs of plants in their changing environments. J. Plant Physiol. 2012, 169, 1664-1672. [CrossRef]

16. Melnikova, N.V.; Dmitriev, A.A.; Belenikin, M.S.; Speranskava, A.S.; Krinitsina, A.A.; Rachinskaia, O.A.; Lakunina, V.A.; Krasnov, G.S.; Snezhkina, A.V.; Sadriidinova, A.F.; et al. Excess fertilizer responsive miRNAs revealed in Linum usitatissimum L. Biochemie 2015, 109, 36-41. [CrossRef]

17. Melnikova, N.V.; Dmitriev, A.A.; Belenikin, M.S.; Koroban, N.V.; Speranskaya, A.S.; Krinitsina, A.A.; Krasnov, G.S.; Lakunina, V.A.; Snezhkina, A.V.; Sadritdinova, A.F.; et al. Identification, expression analysis, and target prediction of flax genotroph microRNAs under normal and nutrient stress sonditions. Plant Biotechnol. 2016, 7, 399. [CrossRef]

18. Poczai, P.; Varga, I.; Laos, M.; Cseh, A.; Bell, N.; Valkonen, J.P.T.; Hyvönen, J. Advances in plant gene-targeted and functional markers: A review. Plant Methods 2013, 9, 6. [CrossRef]

19. Fu, D.; Ma, B.; Mason, A.S.; Xiao, M.; Wei, L.; An, Z. MicroRNA-based molecular markers: A novel PCR-based genotyping technique in Brassica species. Plant Breed. 2013, 132, 375-381. [CrossRef] 
20. Yadav, C.B.Y.; Muthamilarasan, M.; Pandey, G.; Prasad, M. Development of novel microRNA-based genetic markers in foxtail millet for genotyping applications in related grass species. Mol. Breed. 2014, 34, 2219-2224. [CrossRef]

21. Htwe, N.M.P.S.; Luo, Z.Q.; Jin, L.G.; Nadon, B.; Wang, K.J.; Qiu, L.J. Functional marker development of miR1511-InDel and allelic diversity within the genus Glycine. MBC Genom. 2015, 16, 467. [CrossRef]

22. Mondal, T.K.; Ganie, S.A. Identification and characterization of salt responsive miRNA-SSR. Gene 2014, 535, 204-209. [CrossRef] [PubMed]

23. Ganie, S.A.; Mondal, T.K. Genome-wide development of novel miRNA-based microsatellite markers of rice (Oryza sativa) for genotyping applications. Mol. Breed. 2015, 35, 51. [CrossRef]

24. Min, X.; Zhang, Z.; Liu, Y.; Wei, X.; Liu, Z.; Wang, Y.; Liu, W. Genome-wide development of microRNA-based SSR markers in Medicago truncatula with their transferability analysis and utilization in related legume species. Int. J. Mol. Sci. 2017, 18, 2440. [CrossRef]

25. Hlavačková, L.; Nôžková, J.; Porokhovinova, E.; Brutch, N.; Shelenga, T.; Bjelková, M.; Ražná, K. Analysis of miRNA polymorphism during the selected developmental processes of flax. J. Cent. Eur. Agric. 2016, 17, 707-724. [CrossRef]

26. Ražná, K.; Sawinska, Z.; Ivanišová, E.; Vukovic, N.; Terentjeva, M.; Stričík, M.; Kowalczewski, P.L.; Hlavačková, L.; Rovná, K.; Žiarovská, J.; et al. Properties of Ginkgo biloba L.: Antioxidant characterization, antimicrobial activities, and genomic microRNA based marker fingerprints. Int. J. Mol. Sci. 2020, 21, 3087. [CrossRef]

27. Johnson, R.M. Honey bee toxicology. Annu. Rev. Entomol. 2015, 60, 415-434. [CrossRef]

28. Koch, H.; Stevenson, P.C. Do linden trees kill bees? Reviewing the causes of bee deaths on silver linden (Tilia tomentosa). Biol. Lett. 2017, 13, 20170484. [CrossRef] [PubMed]

29. Staudenmayer, T. Die Giftigkeit der Mannose fur Bienen und andere Insekten. J. Comp. Physiol. A Neuroethol. Sen. Neural. Behav. Physiol. 1939, 26, 644-668.

30. Madel, G. Vergiftungen von Hummeln durch den Nektar der Silberlinde Tilia timentosa. Bonn. Zool. Beitr. 1977, $28,149-154$.

31. Ball, T.; Denker, B.; Muhlen, W.; Surholt, B. DieUrsachen des Massensterbens von Hummeln unter spätblühenden Linden. Nat. Landsch. 1994, 69, 412-418.

32. Petanidou, T. Sugars in Mediterranean floral nectars: An ecological and evolutionary approach. J. Chem. Ecol. 2005, 31, 1065-1087. [CrossRef]

33. Ražná, K.; Nôžková, J.; Hlavačková, L.; Brutch, N.; Porokhovinova, E.; Shelenga, T.; Pavlov, A. Genotyping of flax genetic resources by miRNA-based molecular markers and morphology. Agriculture 2015, 61, 129-138. [CrossRef]

34. Griffiths-Jones, S. The microRNA Registry. Nucleic Acids Res. 2004, 32, D109-D111. [CrossRef] [PubMed]

35. Sánchez-Moreno, C.; Larrauri, J.A.; Saura-Calixto, F. A procedure to measure the antiradical efficiency of polyphenols. J. Sci. Food Agric. 1998, 76, 270-276. [CrossRef]

36. Re, R.; Pellegrini, N.; Proteggente, A.; Pannala, A.; Yang, M.; Rice-Evans, C. Antioxidant Activity Applying an Improved ABTS Radical Cation Decolorization Assay. Free Radic. Biol. Med. 1999, 26, 1231-1237. [CrossRef]

37. Singleton, V.L.; Orthofer, R.; Lamuela-Raventós, R.M. Analysis of total phenols and other oxidation substrates and antioxidants by means of folin-ciocalteu reagent. In Methods in Enzymology; Academic Press: Cambridge, MA, USA, 1999; Volume 299, pp. 152-178.

38. Willett, W.C. Balancing life-style and genomics research for disease prevention. Science 2002, 296, 695-698. [CrossRef] [PubMed]

39. Assessment Report on Tilia tomentosa Moench, Flos. Available online: https://www.ema.europa.eu/en/documents/herbalreport/final-assessment-report-tilia-tomentosa-moench-flos_en.pdf (accessed on 18 May 2020).

40. Lande, C.; Rao, S.; Morré, J.T.; Galindo, G.; Kirby, J.; Reardon, P.N.; Bobe, G.; Stevens, J.F. Linden (Tilia cordata) associated bumble bee mortality: Metabolomic analysis of nectar and bee muscle. PLoS ONE 2019, 14, e0218406. [CrossRef] [PubMed]

41. Viola, H.; Wolfman, C.; Levide Stein, M.; Wasowski, C.; Pena, C.; Medina, J.H.; Paladini, A.C. Isolation of pharmacologically active benzodiazepine receptor ligands from Tilia tomentosa (Tiliaceae). J. Ethnopharm. 1994, 44, 47-53. [CrossRef]

42. Cárdenas-Rodríguez, N.; González-Trujano, M.E.; Aguirre-Hernández, E.; Ruíz-García, M.; Sampieri, A.; Coballase-Urrutia, E.; Carmona-Aparicio, L. Anticonvulsant and Antioxidant Effects of Tilia americana var. mexicana and Flavonoids Constituents in the Pentylenetetrazole-Induced Seizures. Oxidative Med. Cell. Longev. 2014, 2014, 329172. [CrossRef]

43. Cordenunsi, B.R.; Oliveira do Nascimento, J.R.; Genovese, M.I.; Lajolo, F.M. Influence of Cultivar on Quality Parameters and Chemical Composition of Strawberry Fruits Grown in Brazil. J. Agric. Food Chem. 2002, 50, 2581-2586. [CrossRef]

44. Pérez-Balibrea, S.; Moreno, D.A.; García-Viguera, C. Influence of light on health-promoting phytochemicals of broccoli sprouts. J. Sci. Food Agric. 2008, 88, 904-910. [CrossRef]

45. Khalili, R.M.A.; Shafekh, S.E.; Norhayati, A.H.; Fatahudin, I.M.; Rahimah, R.; Norkamalia, H.; Azimah, A.N. Total Phenolic Content and in vitro Antioxidant Activity of Winged Bean (Psophocarpus tetragonolobus). Pak. J. Nutr. 2013, 12, 416-422. [CrossRef]

46. Wissam, Z.; Nour, A.A.; Jarkas, B.; Nukari, Z.; Dunia, S. Extracting and studying the antioxidant capacity of polyphenols in dry linden leaves (Tilia cordata). J. Pharmacogn. Phytochem. 2017, 6, 258-262.

47. Buřičová, L.; Réblová, Z. Czech Medicinal Plants as Possible Sources of Antioxidants. Czech J. Food Sci. 2008, 26, 132-138. [CrossRef]

48. Yildirim, A.; Mavi, A.; Oktay, M.; Kara, A.A.; Algur, O.F.; Bilaloglu, V. Comparison of antioxidant and antimicrobial activities of tilia (Tilia argentea Desf ex DC), sage (Salvia triloba L.), and black tea (Camellia sinensis) extracts. J. Agric Food Chem. 2000, 48, 5030-5034. [CrossRef] 
49. Cittan, M.; Altuntaş, E.; Çelik, A. Evaluation of antioxidant capacities and phenolic profiles in Tilia cordata fruit extracts: A comparative study to determine the efficiency of traditional hot water infusion method. Ind. Crop. Prod. 2018, 122, 553-558. [CrossRef]

50. Jia, X.; Yan, J.; Tang, G. MicroRNA-mediated DNA methylation in plants. Front. Biol. 2011, 6, 133-139. [CrossRef]

51. Pickaard, C.S.; Scheid, O.M. Epigenetic Regulation in Plants. Cold Spring Harb. Perspect. Biol. 2014, 6, a019315. [CrossRef] [PubMed]

52. Ma, C.; Burd, S.; Lers, A. miR408 is involved in abiotic stress responses in Arabidopsis. Plant J. 2015, 84, 169-187. [CrossRef] [PubMed]

53. Yang, J.; Wang, G.; Ng, T.B.; Lin, J.; Ye, X. Laccase Production and Differential Transcription of Laccase Genes in Cerrena sp. in Response to Metal Ions, Aromatic Compounds, and Nutrients. Front. Microbiol. 2016, 6, 1558. [CrossRef]

54. Giardina, P.; Faraco, V.; Pezzella, C.; Piscitelli, A.; Vanhulle, S.; Sannia, G. Laccases: A never-ending story. Cell. Mol. Life Sci. 2010, 67, 369-385. [CrossRef] [PubMed]

55. Li, S.B.; Xie, Z.Z.; Hu, C.G.; Zhang, J.Z. A Review of Auxin Response Factors (ARFs) in Plants. Front. Plant Sci. 2016, 7, 47. [CrossRef]

56. Lin, Y.; Lai, Z.; Tian, Q.; Lin, L.; Lai, R.; Yang, M.; Zhang, D.; Chen, Y.; Zhang, Z. Endogenous target mimics down-regulate miR160 mediation of ARF10, -16, and -17 cleavage during somatic embryogenesis in Dimocarpus longan Lour. Front. Plant Sci. 2015. [CrossRef]

57. Yao, X.; Chen, J.; Zhou, J.; Yu, H.; Ge, C.; Zhang, M.; Gao, X.; Dai, X.; Yang, Z.N.; Zhaob, Y. An Essential Role for miRNA167 in Maternal Control of Embryonic and Seed Development. Plant Physiol. 2019, 180, 453-464. [CrossRef]

58. Wang, Y.; Li, K.; Chen, L.; Zou, Y.; Liu, H.; Tian, Y.; Li, D.; Wang, R.; Zhao, F.; Ferguson, B.J.; et al. MicroRNA167-Directed Regulation of the Auxin Response Factors GmARF8a and GmARF8b Is Required for Soybean Nodulation and Lateral Root Development. Plant Physiol. 2015, 168, 101-116. [CrossRef] [PubMed]

59. Kruszka, K.; Pacak, A.; Swida-Barteczka, A.; Nuc, P.; Alaba, S.; Wroblewska, Z.; Karlowski, W.; Jarmolowski, A.; SzweykowskaKulinska, Z. Transcriptionally and post-transcriptionally regulated microRNAs in heat stress response in barley. J. Exp. Bot. 2014, 65, 6123-6135. [CrossRef] [PubMed] 